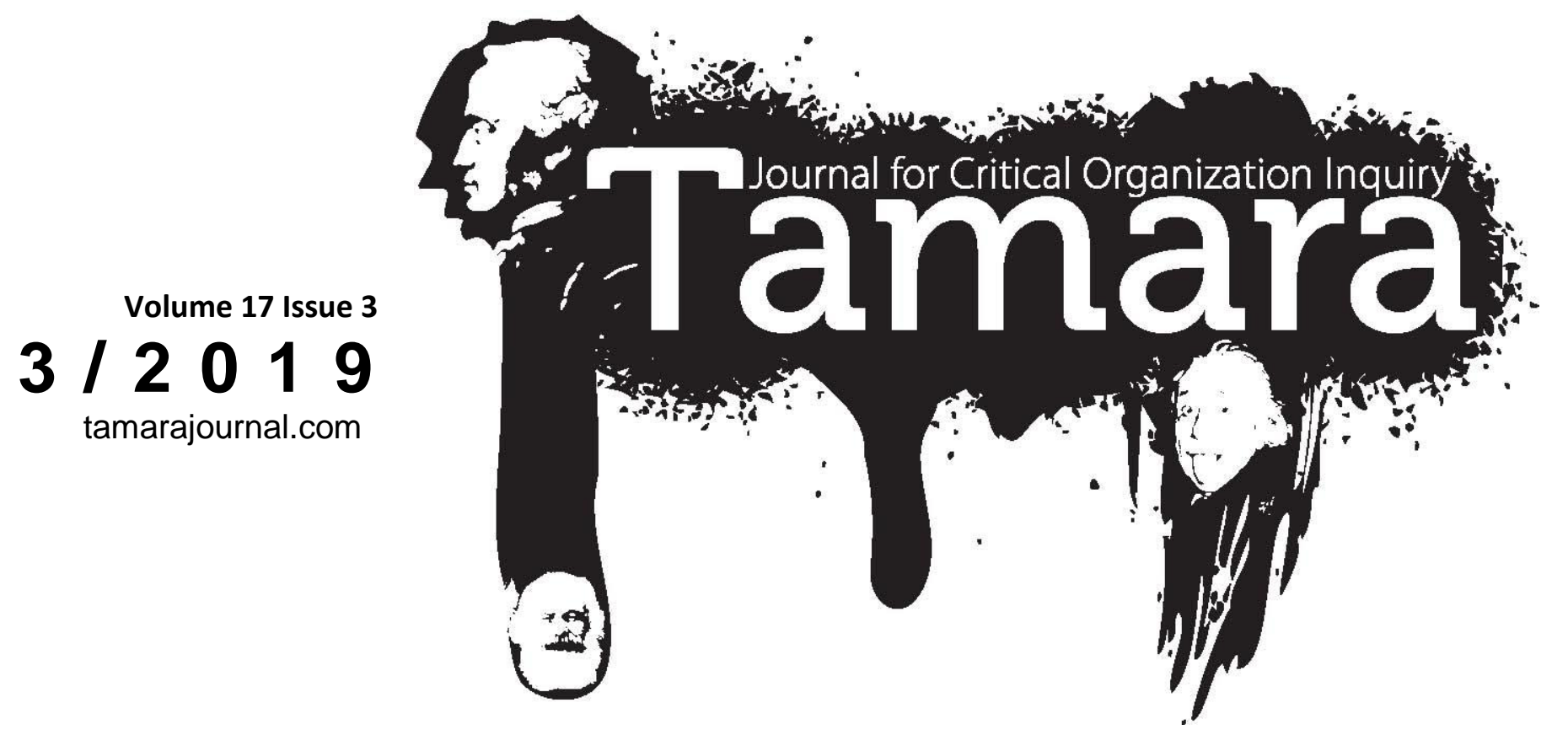

\title{
The effects of social acceleration on the organization-place relationship
}

Dietmar Sternad

Carinthia University of Applied Sciences, Austria

James J. Kennelly

Skidmore College, USA

\section{Keywords \\ sense of place \\ social acceleration \\ organization-place \\ relationship}

field of care

\begin{abstract}
In this conceptual paper, we analyze how social acceleration as a key phenomenon of modern societies affects the relationship between organizations and places. We identify two dimensions of how organizations relate to places: (a) embeddedness (the degree of material integration in a place) and (b) attachment (the psychic closeness, identification, or affective bonds with a place). Building on Rosa's (2003; 2013) seminal work on social acceleration, we further propose three processes (the time-space distanciation effect, the situational identity effect, and the managerial myopia effect) through which temporal changes in modern societies can lead to a loosening of ties between organizations and places. As the attachment to a place may also represent a precondition for organizations to develop a 'field of care,' the framework presented in this paper can help us develop a better understanding of the factors that influence whether organizations can develop a 'sense of place' that fosters responsible social and environmental performance that enhances the well-being of places and communities, respectively.
\end{abstract}

\section{Introduction}

The humanistic geographers (Relph, 1976; Tuan, 1974; 1977) were among the first to distinguish between spaces and "places," defined as "spaces which people have made meaningful" (Cresswell, 2004, p. 7). Yet it is only recently that the organization-place relationship, along with the concept of organizational sense of place, has begun to receive serious attention in the organizational studies literature. The concept of place has manifested itself in the subfields of entrepreneurship (Cohen and Muñoz, 2015; Kibler, Fink, Lang \& Muñoz, 2015), international management (Zaheer and Nachum, 2011), the socio-material experience of work (Berti, Simpson \& Clegg, 2018; Daskalaki, Butler \& Petrovic, 2016), tourism management (Hallak, Brown \& Lindsay, 2012), and the processual nature of management (Hernes, Simpson \& Söderlund, 2013; Sergot and Saives, 2016; Thomas and Cross, 2007), among others. Of more interest to us, 
however, has been the emergence of the concepts of place and sense of place in the literature on corporate social responsibility and sustainability (Elmes, Jiusto, Whiteman, Hersh, \& Guthey, 2012; Guthey, Whiteman, \& Elmes, 2014; Kennedy, Whiteman, \& Von Schwedler, 2017; Shrivastava and Kennelly, 2013), which has focused on the impact of the organization-place relationship upon firm sustainability behaviors and issues of corporate social and environmental performance.

For example, Shrivastava and Kennelly (2013) argue that "place-based" enterprises are more likely than "placeless" enterprises that lack close ties with a place to engage in behaviors that are beneficial for the local community and environment. One possible configuration of the organization-place relationship is the development of an organizational 'field of care,' a deep sense of place that organizations may evince for the places in which they are materially embedded, and to which they are emotionally, cognitively, and physically attached. This in turn may lead to "a sense of deep care and concern for that place" (Relph, 1976, p. 37), a 'field of care' that may be vital for becoming an organization that cares for the well-being of places and communities.

Other recent scholarship on organizations and place has criticized the generally 'placeless' character of much of the organizational literature on sustainability (Guthey et al., 2014; Shrivastava and Kennelly, 2013). Similarly, and although it has long been recognized that space and time are deeply intertwined concepts (not only in physics, but also in the social world) (Giddens, 1984; Taylor and Spicer, 2007), the temporal aspects of the organization-place relationship have also been largely neglected. According to Taylor and Spicer (2007), this is partly due to a "lack of conceptualization of space and place" (p. 326), as well as a "common practice [in social sciences] to privilege the analysis of time [over space and place-related concepts]" (p. 325). In this conceptual paper, we attempt to address this gap by shedding light on how social acceleration, as a salient temporal phenomenon in modern societies (Rosa, 2003; 2013), affects the ways in which organizations relate to places, both materially and psychically.

"Social acceleration" refers to a trend that social life is speeding up in modern societies, both in terms of processes of acceleration within society (mainly determined by technological acceleration and an increasing pace of life) as well as acceleration tendencies of society itself (characterized by an increasing rate of social change) (Hsu and Elliott, 2014; Rosa 2013). According to Rosa and Scheuerman (2009), "social acceleration changes our relationship toward space and time, the natural and material structures surrounding us (the objective world), toward our fellow human beings (the social world), and finally, toward ourselves (the subjective world)" (p. 16). These effects might not be limited to individual human beings; they may potentially apply to organizations as well.

In this paper, we investigate the relationship between societal temporal structures and the ways in which organizations relate to their surroundings, that is, to the places in which they operate. For this purpose, we first explore the relationship between organization and place, and then introduce a framework that aims to reveal the main mechanisms through which social acceleration tendencies can affect the ways that organizations relate to places. A better understanding of the temporal antecedents of the organization-place relationship may help identify factors that are important in enhancing the 'sense of place' of organizations, that may in turn foster responsible social and environmental performance that enhances the well-being of places and communities (Guthey et al., 2014; Kennedy et al., 2017; Shrivastava and Kennelly, 2013).

\section{The relationship between organization and place}

All organizations are to some extent emplaced, attached by weak or strong ties to the places in which they operate. Place, as a "meaningful location" (Cresswell, 2015, p. 12) to which "people are attached to in one way or another" (Cresswell, 2004, p. 7) is a multidimensional construct, dense, dynamic, layered and considerably more complex than mere space or geographic location. Simply put, all organizational life happens in places, along with the associated organizational impacts on communities and the natural environment. One of the more commonly used conceptualizations of place (Agnew, 1987; Gieryn, 2000) includes dimensions of (a) location (latitude and longitude), (b) locale (the material - natural and built - environment), and importantly (but frequently overlooked) (c) sense of place - the social construction of and emotional attachment to place and the investiture of meaning in a place.

But this conceptualization of place, and of organization-place relationships, does not imply stability; places and organizations are both in a constant state of creation and re-creation. As places are remade by organizations, so organizations are remade by the effects of places in a continuous recursive cycle. In this processual view, the organizationplace relationship is constantly renegotiated and ever evolving over time (Gieryn, 2000; Sergot \& Saives, 2016) - a 
"spatio-temporal event" (Massey, 2005, p. 131) that is "unfinished and open" (Sergot \& Saives, 2016) and in which place is created by numberless interactions between human and non-human actors.

None of this obviates the view, however, that organizations are connected to places both materially and emotionally, with varying levels of material embeddedness and place attachment or 'sense of place.' Studies of space and place-related concepts in an organizational science context have, however, often been limited, focusing on distance or proximity aspects (e.g. in the concepts of psychic distance or the CAGE model in international business studies) (Ghemawat, 2001; Håkanson \& Ambos, 2010), while overlooking the ways in which meaning and significance are attributed to a place (Halford, 2004; Taylor and Spicer, 2007).

We use the term place embeddedness in our conceptual model to reflect the degree of integration with and/or dependence upon the material elements of place (the natural/biophysical and built environments) as well as institutional relationships. Firms may be either deeply embedded in specific places, with operations that are integrated and tightly coupled with the material, human, and institutional environments of a place, or quite the opposite. Such embeddedness includes both dependence upon physical and human resources, and deep integration into the social and political institutions of the place. Granted, this type of organization-place relationship is not new to the organizational literature, evidenced for example in resource dependency theory (although with a focus on firm interdependencies and power relationships) (Kono, Palmer, Friedland, \& Zafonte, 1998; Pfeffer and Salancik, 2003), the resource-based view of the firm (with its focus on valuable, rare, and inimitable resources) (Deeds, DeCarolis, \& Coombs, 2000; Peteraf, 1993), and indeed as one of the first and most longstanding interests of the field of international business (Buckley and Ghauri, 2004; Dunning, 1998; Zaheer and Nachum, 2011).

Of more interest, perhaps, is the emotional attachment that organizations (as collections of human beings engaged in a common endeavor) may or may not have to any particular place. Such place attachment is related to identification with a place, or even to topophilia, the affective bond or even love that people (and thereby organizations) may have for a place (Tuan, 1974). It is a sense of the spirit of place, the genius loci or soul of place, that engenders feelings of responsibility and stewardship, or what both Relph (1976, p. 38) and Tuan (1977, p. 412) called a "field of care." This field of care, reflecting organizations that have a "complete commitment to that place, a commitment that is as profound as any" (Relph, 1976, p. 38) is cognitive, emotional, and affective, sometimes indistinct but with the potential, arguably, to be a powerful force in creating 'good' organizations that generate outcomes that redound to the benefit of the places in which they operate.

Indeed, at the individual level of analysis, place attachment has been related to pro-environmental and sustainability behaviors (Coen and Oetama-Paul, 2013) while at the organizational level (Guthey et al., 2014; Shrivastava and Kennelly, 2013; Zaheer \& Nachum, 2011) organizational sense of place has been linked to organizations paying "more attention to places as complex emergent and lived phenomena [which] may improve organizational understanding of the environment, community, and other elements important for sustainability" (Guthey et al., 2014, p. 262).

Attachment and embeddedness may themselves interact in complex ways; attachment may beget embeddedness, and vice versa. A strong affective commitment to a certain place can, for example, induce organizational leaders to favor local partners over overseas suppliers, thus increasing the organization's material embeddedness. Stronger business relationships with people and other organizations in a certain place can, in turn, lead to higher levels of trust and emotional attachment to these partnerships and therefore also - especially if many partners are located in one particular place - to a place. Organizations that evince both strong embeddedness and a deep place attachment have been described as placebased enterprises, while those without such embeddedness or attachment have been posited to represent placeless organizations (Shrivastava and Kennelly, 2013). But both place embeddedness and place attachment usually develop over time (Andersson, Björkman, \& Forsgren, 2005; Lewicka, 2011; Nostrand and Estaville Jr., 1993) and are shaped by countless experiences. Following this logic, as well as Sergot \& Saives (2016) who argued in their study of Doreen Massey that "space and time are interlocked and must be thought of as such" (p. 339), we can therefore posit that temporal aspects may also play an important role in the organization-place relationship.

\section{The phenomenon of social acceleration}

The progressively increasing pace of social life or 'social acceleration' has been recognized and described by a range of scholars as a key tendency (and even constituent factor) of modernity (e.g. Agger, 2004; Conrad, 1999; Scheuerman, 
2004; Simmel, 2009; Tomlinson, 2007). According to Rosa and Scheuerman (2009), "it is now something of a commonplace that core social and economic processes are undergoing a dramatic acceleration, while general rates of social change are intensifying no less significantly" (p. 2). It is only recently, however, that we can observe the development of systematic theories to explain this societal development (Vostal, 2014).

A seminal contribution for our understanding of social acceleration is the work of Rosa (2013). By distinguishing three dimensions of social acceleration, Rosa (2013) highlights the multifaceted nature of this phenomenon:

- technological acceleration, for example in the fields of communication, production, or transport, allowing us to reduce the time needed for "goal-directed processes" (p. 74);

- acceleration of the pace of life "through an increase of episodes of action and/or experience per unit of time" (p. 64); and

- acceleration of society as a whole, characterized by an increasing rate of change of social expectations and relationship patterns.

The tripartite structure of social acceleration has also been confirmed in empirical work by Ulferts, Korunka, and Kubicek (2013). In addition to identifying several external drivers for social acceleration (in particular, the inherent logic of the capitalist system, functional differentiation, and the cultural promise of acceleration), Rosa (2013) also postulates that the three dimensions of social acceleration reinforce each other in a self-propelling spiral. New technologies necessitate the adaptation of societal structures. New modes of transport or communication, for example, have consequences for the ways in which people arrange their social relations (Jensen, 2006). Constant social change, in turn, is a strong driving force for increasing the pace of life, as, according to Rosa (2013), people have a fear of missing out in the face of a "runaway world" (Giddens, 1999). The faster the pace of life, the higher is the demand for time-saving technology, which further fuels the acceleration cycle (Rosa, 2013).

Social acceleration has an impact on societal structures in general, and on organizations more particularly. Many business executives regard acceleration tendencies in society and the resulting time pressure as "the core organizational challenge that has emerged over the last twenty years" (Sabelis, 2007, p. 261). Indeed, acceleration tendencies were found to have various negative effects on organizations, including generating anxieties and emotional exhaustion (Korunka, Kubicek, Paškvan, \& Ulferts, 2015; Szollos, 2009), increasing competitive pressure (Saraiva and Inglesias, 2015), prompting "fast activism" to take precedence over long-term planning (Petrick 2016), and a diminished inclination to find integrative solutions for problems that affect various parties (De Dreu, 2003).

But changes in how we relate to time can, in a more general sense, also impact how people and organizations (as entities that people create to reach certain common goals) generally relate to the world. According to Rosa (2013), "our being-in-the-world depends to a great degree on the temporal structures (Zeitstrukturen) of the society in which we live." (p. xxxviii). The way in which we relate - in a physical and psychic sense - to places is an important facet of 'our beingin-the-world.' Therefore, we will attempt to explore and clarify the ways in which these temporal structures of our modern world - which are strongly determined by the processes of social acceleration - affect the complex relationship between organizations and places.

\section{How social acceleration affects the organization - place relationship}

The relationship between time and space in a societal context has been addressed by various scholars, including, for example, Giddens (1985), Massey (1999), Robertson (1991) and Sergot \& Saives, (2016). In a recent contribution, Rosa (2013) notes that in our modern society "the transformation of spatiotemporal structures is primarily driven by its temporal dynamic of change" (p. 29). Social acceleration can change our individual and collective relationships toward the "objective world" (Rosa and Scheuerman, 2009, p. 17), and thus by extension to places. A commonly noted effect of the speeding up of social life is an increasing detachment from places, as succinctly summarized by Virilio (1994): "Today, the strategic value of speed's 'no place' has definitely outstripped the value of place" (p. 31).

In the following, we examine the processes through which the three dimensions of social acceleration (technological acceleration, acceleration of the pace of life, and acceleration of society as a whole) can influence place embeddedness and place attachment as two dimensions of the relationship between organization and place (see Figure 1 for an overview). 
Dimensions of social acceleration (Rosa, 2013)
Effects of social acceleration
Dimensions of the organization-place relationship

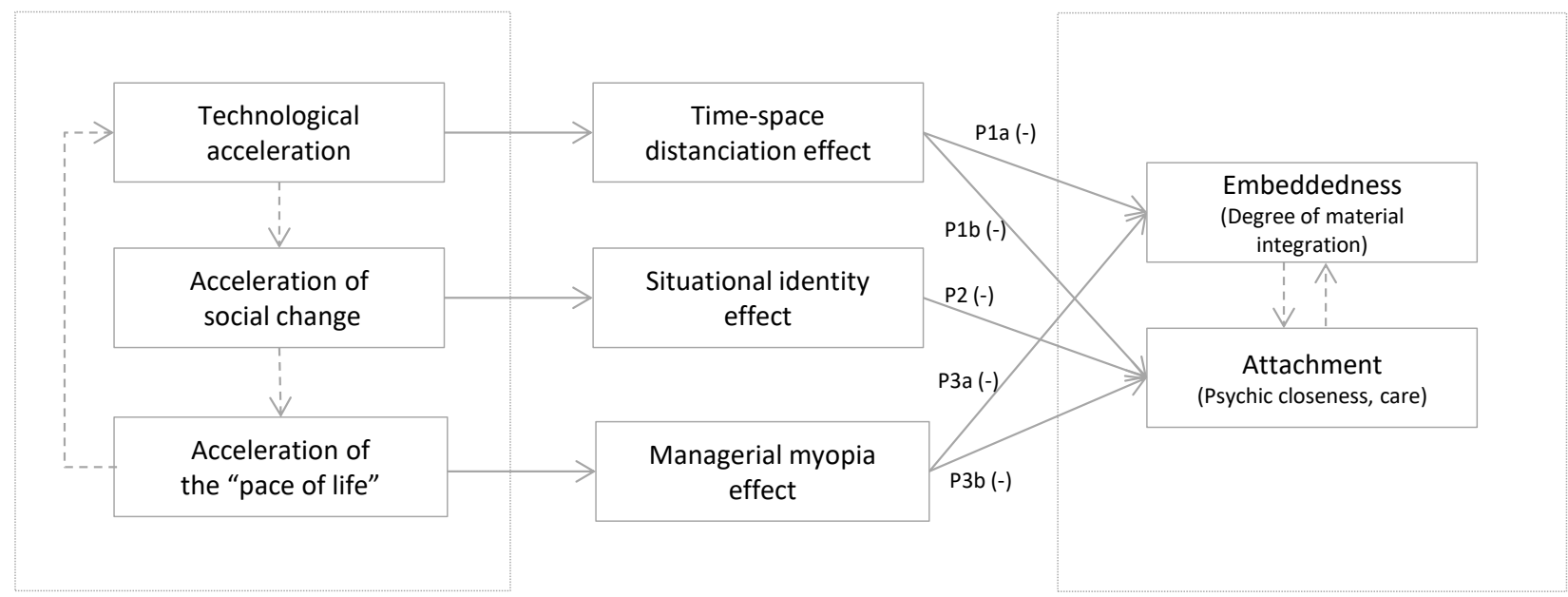

Figure 1: The link between social acceleration and the organization-place relationship

\section{The time-space distanciation effect}

The invention of cars, airplanes, telephones, and the Internet has dramatically increased the speed with which both people and information can overcome distances. Technological acceleration means that resources can move faster and more cheaply between different locations, thus becoming more accessible despite distance. As a consequence of this "time-space compression" (Harvey, 1989, p. 24) organizations are less physically bound to certain places in order to gain access to resources. Multinational corporations in particular, already characterized by mobility advantages and their ability to arbitrage opportunities globally, may thereby further loosen their ties to, or embeddedness in, particular places.

Giddens (1984) refers to the term "time-space distanciation" to describe the separation between time and space and the resulting temporal and spatial disembeddedness of social relations as a consequence of technological acceleration. Sabelis (2007), for example, noticed that executives expand their spatial horizons as a consequence of societal acceleration, as they recognize the importance of integrating their organizations in international networks in order to keep up-to-date with global developments.

Time-space distanciation also means that relationships between individuals (or organizations, respectively) are no longer bound to local contexts or specific places. Therefore, as relationships become spatially fragmented, "[t]he primacy of place ... has been largely destroyed by disembedding and time-space distanciation" (Giddens, 1990, p. 108). As the concentration of social relationships in one particular place - the "presence-availability" (i.e. the presence of others with whom one has social bounds in physical proximity) in Giddens' (1984) terms - is reduced, the socially-determined emotional attachment of individual actors, and in aggregation of organizations, to that place will also tend to be reduced. As time and space compress, the relationships to both people and places become transitory or "liquid" (Bauman, 2000).

These arguments lead us to the following propositions:

- Proposition la: Technological acceleration through time-space distanciation makes resources in distant places more readily available and therefore tends to reduce organizational embeddedness in place.

- Proposition 1b: Technological acceleration through time-space distanciation reduces physical and informational travel times, makes people more mobile and therefore reduces individual and organizational attachment to any one particular place.

\section{The situational identity effect}

Building on the work of Mead (1932), Flaherty and Fine (2001) postulate that "the self is, above all, a temporal process" (p. 157), determined by the past (its biographical history) as well as by the future (characterized by its intentions, goals, and purposes) and the present (being in the world). In a similar vein, Jenkins (2002) observes that "time and identification are intimately bound together" (p. 268). He argues that in order to form a stable identity, it is important to 
have a shared awareness of our past and an imagination of what we want to become in the future. This is not only the case for individual people, but also for organizations (Turnbull, 2004).

To achieve a stable identity, however, we need continuity and "some kind of stable present" (Jenkins, 2002, p. 275), which is difficult to achieve in light of constant social change. Both personal and organizational identities are not only related to time (and continuity of time, in particular), but also to how people or organizations relate to the outside world, and in particular to places (Lewicka, 2011; Schultz and Hermes, 2013). The concept of place itself is inextricably related to the experience of time: timelessness, stability, or accelerating time all affect the creation and the experience of place (Relph, 1976), either cementing or eroding a sense of place. Links with a place can provide a "sense of continuity," thus contributing to the development of a stable and strong identity (Twigger-Ross and Uzzell, 1996). In Casey's (2001) words, "there is no place without self and no self without place." (p. 684, emphasis in the original). Thus, the spatial aspect of organizational identity - in terms of either closeness or distance to other organizations or attachment to certain places also needs to be taken into account as we consider the "interplay between temporal and spatial dimensions of identity" (Clegg, Rhodes, \& Kornberger, 2007, p. 506).

In an environment that is characterized by constant change of society, identities become more transitory or "situational" as formerly stable identity patterns dissolve into "identity sequences" (Rosa, 2013, p. 148). As the "contents of the world" are constantly changing, as new social arrangements and structures emerge, new technologies develop, new opportunities arise, new players appear on the stage, and relationships become more transient, the self is becoming "detached" when "self-transformation becomes a mundane practice" (Hsu and Elliott, 2014, p. 402). Both individuals and organizations are constantly open to renegotiating their identities. Organizations, in particular, feel a pressure to constantly reinvent themselves (Erturk and Solari, 2007). Elliott (2013) even speaks of a "reinvention society" (p. 95) that leads to a heightened risk of "obliteration of value and meaning" (p. 6) and a general devaluation of tradition (Giddens, 1991). As a consequence, lives and identities become fragmented, and "movement from one locale and culture to another with little residual effect" (Gergen, 2000, p. 172) becomes more common. Thus, identity loses its boundedness to place. In Rosa's (2013) words, "[h]uman existence tends to become placeless" (p. 106), both on an individual and collective (organizational) level. This leads to the following:

- Proposition 2: Acceleration of social change makes organizational identities more situational, reducing organizational attachment to any one particular place.

\section{The managerial myopia effect}

Finally, Rosa (2013) identifies a faster pace of life, defined as "the increase of episodes of action and/or experience per unit of time" (p. 64) as another key dimension of social acceleration. A faster pace of life usually coincides with a higher level of perceived time scarcity. Managers, in particular, report chronic time pressure, as they live and work with a constant feeling of "being rushed" (Szollos, 2007). Consequently - and in combination with an acceleration tendency in the competitive market space - a "high-speed management" style has proliferated since the 1990s (Cushman and King, 1993; 1995). The short term takes precedence over the long term in corporate decision-making processes, a phenomenon also known as "managerial myopia" (Laverty, 2004), which has been discussed by scholars in different disciplines of management and organizational studies (Chen et al., 2015; Slawinski and Bansal, 2015; Sternad and Kennelly, 2017). Empirical studies have, for example, shown that many top managers are willing to compromise long-term value creation in favor of short-term business goals (Graham, Harvey, \& Rajgopal, 2006; Grinyer, Russell, \& Collison, 1998). Endeavoring to optimize short-term results, they may also be more willing to compromise long-term relationships with places, as short-term possibilities for geographic arbitrage (exploiting price differences between different locations) arise (Ghemawat, 2008). While resource cost advantages can quite easily be reached through geographic arbitrage in the short term, staying in a certain place often means that cost advantages can only be achieved in the long run (e.g., through investment in production capacity and technology or experience curve effects).

The faster pace of the managerial work also means that there is less time for building trusting, mutually beneficial relationships. Rosa (2013) sees "a tendential loosening of concrete ties to particular persons, places, or things" (p. 304, emphasis by the authors) as a consequence of societal acceleration. With a lack of strong personal ties to places by the top management team, it is also unlikely that organizations can form a strong emotional connection - or attachment - to places. We therefore conclude that: 
- Proposition 3a: Acceleration of the pace of life leads to increased managerial short-termism, which, in turn, increases the willingness to engage in geographic arbitrage, reducing organizational embeddedness in a place.

- Proposition 3b: Acceleration of the pace of life leads to increased managerial short-termism, which, in turn, reduces the ability and willingness to engage in long-term relationships, reducing the organizational attachment to a place.

\section{Discussion and conclusion}

With this paper, we provide a framework for analyzing how societal acceleration tendencies contribute to the development of "placeless" organizations. We identify three processes that contribute to the detachment of organizations from places and to a subsequent destabilizing effect on organizational identities:

1. Following Giddens (1984), we propose that technological acceleration, especially in the fields of transport and communication, is disembedding organizations from places through a time-space distanciation effect (as it is getting easier to obtain resources and maintain relationships over a distance).

2. Building on identity theory, we recognize a link between the acceleration of social change and the emergence of more transient and situational organizational identities (the situational identity effect).

3. Finally, we also suggest that an acceleration of the pace of life in society leads to managerial short-termism, which, in turn, reduces the ability and willingness of organizations to engage in long-term relationships with particular places (the managerial myopia effect).

With our analysis, we make several contributions to the emerging literature on the relationship between organizations and places. In general, we hope to fuel a discussion on the integration of temporal and spatial perspectives in organizational science. As many other disciplines have already recognized, time and space are intrinsically related. Therefore, it makes sense to take a closer look at the intersections of these two fundamental concepts in an organizational context. More specifically, we also highlight the two-dimensional nature of the organization-place relationship, as we distinguish between place embeddedness (the degree to which organizations are tightly coupled with the material and human environments of a place) and place attachment (the affective bonds and commitments that exist between organizations and a place), and also propose that developments in societal temporal structures can have effects on both dimensions. This distinction between place embeddedness and place attachment could also inform future empirical work on the strengths of relationships between organizations and certain places. We also unveil some societal mechanisms that might induce organizations to exhibit less care for places and reduce their place-related sustainability behaviors (Shrivastava and Kennelly, 2013). Placeless organizations, being left without a 'field of care,' are also less likely to become 'good organizations,' at least in terms of their positive impact on places.

The framework presented in Figure 1 offers more than just a passive evaluation of developments in the relationship between societal temporal tendencies and the relationship between organizations and places. It also begs the question of potential intervention strategies that can help to 're-embed' organizations in places. Admittedly, the time-space distanciation effect of technological acceleration seems difficult to counteract. Organizations cannot completely decouple themselves from technological developments that bring resources and relationships in more distant places within closer reach. The situational identity and managerial myopia effects are not inevitable, however. On one hand, organizations can deliberately decide to build their identity based on their relationship with a particular place. The levelling of differences as a consequence of the compression of distance has also led to a revaluation of the importance of local and regional idiosyncrasies (Harvey, 1990; Rosa, 2013), demonstrated, for example, by the increasing demand for local or regional products. According to Casey (1997), "sameness-of-place on a global scale . . makes the human subject long for a diversity of place" (p. xiii). "Place-based enterprises" (Shrivastava and Kennelly, 2013) can use the demand for regional specificity to their advantage. On the other hand, both policy makers and top managers can deliberately decide to take a more long-term oriented approach (as practiced, for example, by many family-controlled enterprises) (Sternad, 2013), thus fostering the building of stronger ties in - and thereby also with - certain places.

As our analysis shows, social acceleration tendencies can indeed become a challenge for the development of organizations that care not only for economic success, but also for the well-being of places and communities. But as "intentional deceleration" (Rosa, 2013, p. 87) movements in other societal domains are trying to slow down the pace of 
life (e.g. in the case of the 'slow food' movement, which emphasizes regionally sourced ingredients, or the 'patient capital' movement, which takes a long-term approach to realizing returns), so can responsible managers influence the way in which they react to social acceleration tendencies, and thereby have a real effect on whether their organizations will be 'good' for a certain place.

Of course, our paper is not without limitations. We did not consider the potential interplay between time-space distanciation, organizational identity, and managerial temporal orientation. We also did not examine the processes by which both organizational identities and meanings of a place and attachments to a place are created and shared (or not) among organizational members (He and Brown, 2013; Low, 1992), nor the potential conflicts inherent in such heterogeneity of individual relationships to place or the ways in which such differences are negotiated (Sergot \& Saives, 2016). Future research must also consider that embeddedness, attachment, and identity can be influenced by both the quantity and the quality of ties that bind organizations to a certain place (Stets and Burke, 2000) as well as by additional factors in the economic, institutional and cultural environment (e.g. transaction costs, local content requirements, or cultural differences in temporal focus) (Guo et al., 2012; Hufbauer et al., 2013; Porter, 1998).

We must also acknowledge that definitions of place remain contestable, and the construct that we have employed in this paper is but one of many approaches. For example, our more "positional" conception of place would certainly stand in contrast to Massey's more "extroverted notion of place" (Creswell, 2015, p. 20) which focuses upon place as relational, open, heterogeneous, dynamic, conflicted, and always unfinished (Massey, 2005; Sergot \& Saives, 2016). These limitations of our paper, however, also open new research opportunities.

In summary, we regard our conceptual work as merely a tentative step in a more elaborate and extended exploration of the relationship between time and place in an organizational context. In addition to empirical studies to test the three suggested effects of social acceleration on organizational embeddedness and attachment to places, further research could also take a multi-level approach and analyze the interrelation between temporal orientations and temporal structures on different levels (e.g. societal level, organizational level, level of individual managers) and commitments of organizations to places on different levels (e.g. neighborhoods, cities, regions, countries, or continents). Of particular interest in the context of creating socially responsible and sustainable organizations is a further exploration of the combined impact of temporal aspects - e.g. "residence length" (Lewicka, 2011) of an organization in a place - and place embeddedness and/or attachment on socially and environmentally sustainable actions of organizations in particular places. Taking time and place-related variables into account simultaneously could thus potentially provide a new perspective on studying corporate social responsibility and sustainability-related issues in organizations. Further research could also try to explore whether place embeddedness and place attachment also play a role in exhibiting a high level of care for social and environmental sustainability not only on a local but also on a global level, or if a strong focus on the local environment could actually distract organizational actors from global issues like climate change.

Finally, we also need to take into account that the meaning of places can, and surely must, be renegotiated over time, thus affecting both attachments and commitments (Hauge, 2007). Time, place, and organizations are in dynamic interplay with each other. We believe that there should be a place in organizational sciences for exploring these complex dynamics, and their critically important effects.

\section{References}

Agger, B. (2015). Speeding up fast capitalism: Cultures, jobs, families, schools, bodies. London: Routledge.

Agnew, J. (1987). The United States in the world economy. Cambridge, England: Cambridge University Press.

Andersson, U., Björkman, I., \& Forsgren, M. (2005). Managing subsidiary knowledge creation: The effect of control mechanisms on subsidiary local embeddedness. International Business Review, 14(5), 521-538.

Bauman, Z. (2000). Liquid modernity. Cambridge: Polity Press.

Berti, M., Simpson, A. V., \& Clegg, S. R. (2018). Making a place out of space: The social imaginaries and realities of a Business School as a designed space. Management Learning, 49(2), 168-186.

Buckley, P. J., \& Ghauri, P. N. (2004). Globalisation, economic geography and the strategy of multinational enterprises. Journal of International Business Studies, 35(2), 81-98.

Casey, E. S. (1997). The fate of place: A philosophical history. Berkeley: University of California Press. 
Casey, E. S. (2001). Between geography and philosophy: What does it mean to be in the place-world? Annals of the Association of American Geographers, 91(4), 683-693.

Chen, Y. F., Lin, F. L., \& Yang, S. Y. (2015). Does institutional short-termism matter with managerial myopia?. Journal of Business Research, 68(4), 845-850.

Clegg, S. R., Rhodes, C., \& Kornberger, M. (2007). Desperately seeking legitimacy: Organizational identity and emerging industries. Organization Studies, 28(4), 495-513.

Coen, C. \& Oetama-Paul, A. (2013). Place attachment: Capturing causes of individual pro-environmental behaviors in the workplace. Academy of Management Proceedings, 2013:1 13969.

Cohen, B. \& Muñoz, P. (2015). Toward a theory of purpose-driven urban entrepreneurship. Organization and Environment, 28(3), 264-285.

Conrad, P. (1999). Modern times, modern places. New York, NY: Knopf.

Cushman, D. P., \& King, S. S. (1993). High-speed management: A revolution in organizational communication in the 1990s. Annals of the International Communication Association, 16(1), 209-236.

Cushman, D. P. \& King, S. S. (1995). Communication and high-speed management. Albany, NY: State University of New York Press.

Creswell, T. (2004). Place: A short introduction. Oxford: Blackwell Publishing.

Daskalaki, M., Butler, C.L. \& Petrovic, J. (2016). Somewhere in-between: Narratives of place, identity, and translocal work. Journal of Management Inquiry, 25(2), 184-198

De Dreu, C. K. (2003). Time pressure and closing of the mind in negotiation. Organizational Behavior and Human Decision Processes, 91(2), 280-295.

Deeds, D. L., DeCarolis, D., \& Coombs, J. (2000). Dynamic capabilities and new product development in high technology ventures: An empirical analysis of new biotechnology firms. Journal of Business Venturing, 15(3), 211-229.

Dunning, J. H. (1998). Location and the multinational enterprise: A neglected factor. Journal of International Business Studies, 29(1), 45-66.

Elliott, A. (2013). Reinvention. New York, NY: Routledge.

Elmes, M.B., Jiusto, S., Whiteman, G., Hersh, R. \& Guthey, G.T. (2012). Teaching social entrepreneurship and innovation from the perspective of place and place making. Academy of Management Learning \& Education, 11(4), $533-554$.

Erturk, I., \& Solari, S. (2007). Banks as continuous reinvention. New Political Economy, 12(3), 369-388.

Flaherty, M. G., \& Fine, G. A. (2001). Present, past, and future. Time \& Society, 10(2-3), 147-161.

Gergen, K. J. (2000). The saturated self: Dilemmas of identity in contemporary life. New York, NY: Basic Books.

Ghemawat, P. (2001). Distance still matters. Harvard Business Review, 79(8), 137-147.

Ghemawat, P. (2008). Reconceptualizing international strategy and organization. Strategic Organization, 6(2), $195-206$.

Giddens, A. (1984). The constitution of society: Outline of the theory of structuration. Berkeley, CA: University of California Press.

Giddens, A. (1985). Time, space and regionalisation. In Gregory, D. \& Urry, J., Social relations and spatial structures (pp. 265-295). Palgrave, London.

Giddens, A. (1990). The consequences of modernity. Stanford, CA: Stanford University Press.

Giddens, A. (1991). Modernity and self-identity: Self and society in the late modern age. Stanford, CA: Stanford University Press.

Gieryn, T.F. (2000). A space for place in sociology. Annual Review of Sociology, 26, 463-496.

Guo, T., Ji, L. J., Spina, R., \& Zhang, Z. (2012). Culture, temporal focus, and values of the past and the future. Personality and Social Psychology Bulletin, 38(8), 1030-1040.

Graham, J. R., Harvey, C. R., \& Rajgopal, S. (2006). Value destruction and financial reporting decisions”, Financial Analysts Journal, 62(6), 27-39.

Grinyer, J., Russell, A., \& Collison, D. (1998). Evidence of managerial short-termism in the UK. British Journal of Management, 9(1), 13-22.

Guthey, G., Whiteman, G., \& Elmes, M. (2014). Place and sense of place: Implications for organizational studies of sustainability. Journal of Management Inquiry, 23(3), 254-265. 
Håkanson, L., \& Ambos, B. (2010). The antecedents of psychic distance. Journal of International Management, 16(3), 195-210.

Halford, S. (2004). Towards a sociology of organizational space. Sociological Research Online, 9(1). Available at: http://www.socresonline.org.uk/9/1/halford.html

Hallak, R., Brown, G. \& Lindsay, N.J. (2012). The place identity - performance relationship among tourism entrepreneurs: A structural equation modelling analysis. Tourism Management, 33(1), 143-154

Harvey, D. (1989). The condition of postmodernity: An enquiry into the origins of cultural change. Oxford: Blackwell.

Hauge, Å. L. (2007). Identity and place: a critical comparison of three identity theories. Architectural Science Review, 50(1), 44-51.

He, H., \& Brown, A. D. (2013). Organizational identity and organizational identification: A review of the literature and suggestions for future research. Group \& Organization Management, 38(1), 3-35.

Hernes, T., Simpson, B. \& Söderlund, J. (2013). Managing and temporality. Scandinavian Journal of Management, 19(1), 1-6.

Hsu, E. L., \& Elliott, A. (2015). Social acceleration theory and the self. Journal for the Theory of Social Behaviour, 45(4), 397-418.

Hufbauer, G. C., Schott, J. J., \& Cimino-Isaacs, C. (2013). Local content requirements: A global problem (Policy Analyses in International Economics Vol. 102). Washington, DC: Peterson Institute for International Economics.

Jenkins, R. (2002). In the present tense: Time, identification and human nature. Anthropological Theory, 2(3), 267-280.

Jensen, M. (2006). Environment, mobility, and the acceleration of time: A sociological analysis of transport flows in modern life. In: Spaargaren, G., Mol, A., \& Buttel, F. (eds.), Governing environmental flows in modern life: Global challenges to social theory (pp. 326-350). Cambridge, MA: The MIT Press.

Kennedy, S., Whiteman, G. \& Von Schwedler, M. (2017). A place-based analysis of sustainable water management. In Guerber, A. J., Markman, G. D. \& Chih-Yi Su, S. (eds.), The World Scientific Reference on Entrepreneurship, Vol. 3: Sustainability, Ethics and Entrepreneurship (pp. 159-192). New Jersey: World Scientific.

Kibler, E., Fink, M., Lang, R. \& Muñoz, P. (2015). Place attachment and social legitimacy: Revisiting the sustainable entrepreneurship journey. Journal of Business Venturing Insights, 3, 24-29.

Kono, C., Palmer, D., Friedland, R., \& Zafonte, M. (1998). Lost in space: The geography of corporate interlocking directorates. American Journal of Sociology, 103(4), 863-911.

Korunka, C., Kubicek, B., Paškvan, M., \& Ulferts, H. (2015). Changes in work intensification and intensified learning: challenge or hindrance demands? Journal of Managerial Psychology, 30(7), 786-800.

Laverty, K. J. (2004). Managerial myopia or systemic short-termism. Management Decision, 42(8), 949-962.

Lewicka, M. (2011). Place attachment: How far have we come in the last 40 years? Journal of Environmental Psychology, 31(3), 207-230.

Low, S. M. (1992). Symbolic ties that bind. In: Altman, I. \& Low, S. M. (eds.). Place attachment (pp. 165-185). New York: Plenum Press.

Massey, D. (2005). For space. London: Sage.

Massey, D. (1999). Space-time, 'science' and the relationship between physical geography and human geography. Transactions of the Institute of British Geographers, 24(3), 261-276.

Nostrand, R. L., \& Estaville Jr, L. E. (1993). Introduction: The homeland concept. Journal of Cultural Geography, 13(2), $1-4$.

Peteraf, M. A. (1993). The cornerstones of competitive advantage: A resource-based view. Strategic Management Journal, 14(3), 179-191.

Petrick, K. (2016). Strategic planning in the 'empire of speed'. Globalizations, 13(3), 345-359.

Pfeffer, J., \& Salancik, G. R. (2003). The external control of organizations: A resource dependence perspective. Stanford, CA: Stanford University Press.

Porter, M. E. (1998). Clusters and the new economics of competition. Harvard Business Review, 76(6), 77-90.

Relph, E. (1976). Place and placelessness. London: Pion.

Robertson, R. (1995). Glocalization: Time-space and homogeneity-heterogeneity. In: Featherstone, M., Lash, S., \& Robertson, R., Global modernities (pp. 25-44). London: Sage. 
Rosa, H. (2003). Social acceleration: Ethical and political consequences of a desynchronized high-speed society. Constellations, 10(1), 3-33.

Rosa, H. (2013). Social acceleration: A new theory of modernity. New York, NY: Columbia University Press.

Rosa, H. \& Scheuerman, W. E. (2009). Introduction. In: Rosa, H. \& Scheuerman, W. E. (ed.), High-speed society: Social acceleration, power, and modernity (pp. 1-29). University Park, PA: The Pennsylvania State University Press.

Sabelis, I. H. J. (2007). The clock-time paradox: Time regimes in the network society. In Hassan, R. \& Purser, R. E., 24/7: Time and temporality in the network society (pp. 255-278). Stanford, CA: Stanford University Press.

Saraiva, R., \& Iglesias, F. (2016). Cooperation under pressure: Time urgency and time perspective in social dilemmas. Time \& Society, 25(2), 393-405.

Scannell, L., \& Gifford, R. (2010). Defining place attachment: A tripartite organizing framework. Journal of Environmental Psychology, 30(1), 1-10.

Scheuerman, W. E. (2004). Liberal democracy and the social acceleration of time. Baltimore: John Hopkins University Press.

Schultz, M., \& Hernes, T. (2013). A temporal perspective on organizational identity. Organization Science, 24(1), 1-21.

Sergot, B., \& Saives, A. L. (2016). Relating place to organization: A situated tribute to Doreen Massey. M@n@gement, 19(4), 335-352.

Shrivastava, P. \& Kennelly, J. J. (2013). Sustainability and place-based enterprise. Organization \& Environment, 26(1), 83-101.

Simmel, G. (2009). The pace of life and the money economy. In: Rosa, H. \& Scheuerman, W. E. (ed.), High-speed society: Social acceleration, power, and modernity (pp. 41-56). University Park, PA: The Pennsylvania State University Press.

Slawinski, N., \& Bansal, P. (2015). Short on time: Intertemporal tensions in business sustainability. Organization Science, 26(2), 531-549.

Sternad, D. (2013). Managerial long-term responsibility in family-controlled firms. Management, 8(2), 93-107.

Sternad, D., \& Kennelly, J. J. (2017). The sustainable executive: Antecedents of managerial long-term orientation. Journal of Global Responsibility, 8(2), 179-195.

Stets, J. E., \& Burke, P. J. (2000). Identity theory and social identity theory. Social Psychology Quarterly, 63(3), $224-237$.

Szollos, A. (2009). Toward a psychology of chronic time pressure: Conceptual and methodological review. Time \& Society, 18(2-3), 332-350.

Taylor, S., \& Spicer, A. (2007). Time for space: A narrative review of research on organizational spaces. International Journal of Management Reviews, 9(4), 325-346.

Thomas, D. F. \& Cross, J. E. (2007). Organizations as place builders. Journal of Behavioral and Applied Management, 9(1), 33-61.

Tomlinson, J. (2007). The culture of speed: The coming of immediacy. London: Sage.

Tuan, Y. (1977). Space and place: The perspective of experience. Minneapolis, MN: University of Minnesota Press.

Tuan, Y. (1974). Topophilia: A study of environmental perception, attitudes, and values. Englewood Cliffs, NJ: PrenticeHall.

Turnbull, S. (2004). Perceptions and experience of time-space compression and acceleration: The shaping of leaders' identities. Journal of Managerial Psychology, 19(8), 809-824.

Twigger-Ross, C. L., \& Uzzell, D. L. (1996). Place and identity processes. Journal of Environmental Psychology, 16(3), 205-220.

Ulferts, H., Korunka, C., \& Kubicek, B. (2013). Acceleration in working life: An empirical test of a sociological framework. Time \& Society, 22(2), 161-185.

Virilio, P. (1994). The vision machine. Bloomington, IN: Indiana University Press.

Vostal, F. (2014). Thematizing speed: Between critical theory and cultural analysis. European Journal of Social Theory, 17(1), 95-114.

Zaheer, S., \& Nachum, L. (2011). Sense of place: From location resources to MNE locational capital. Global Strategy Journal, 1(1-2), 96-108. 